بهترين تركيب وزنى شاخصها در بهرهبردارى بهينه از كانالهاى آبيارى با استفاده از روش SA و كاربرد روش مجانب در اعتبارسنجى آن

سيد اسداله محسنى موحد "*

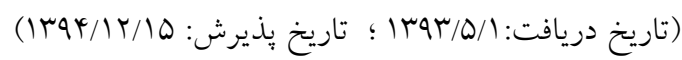

جكيده

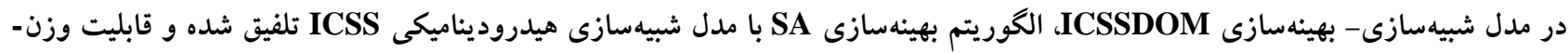

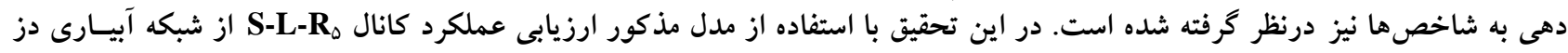

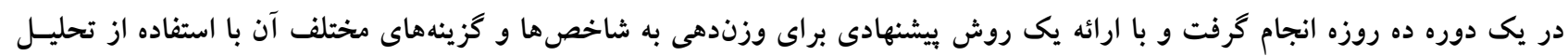

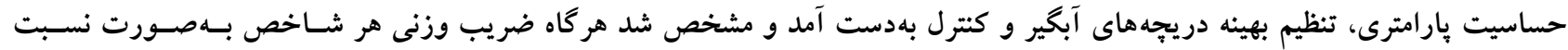

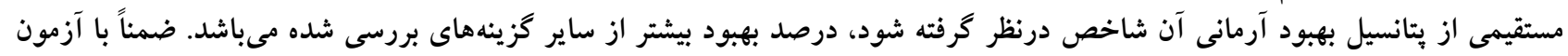

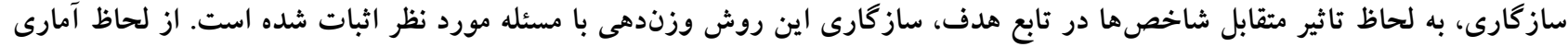

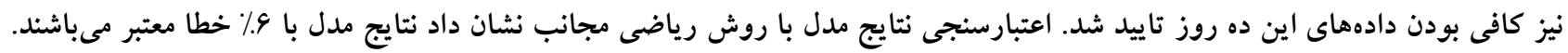

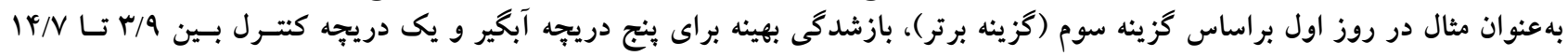

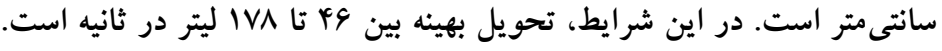

وازگكان كليدى: آزمون سازگارى، الخوريتم SA، يتانسيل بهبود آرمانى، روش مجانب، مدل ICSSDOM 
SA را انجام دادند. ايشان با مقايسة تركيب مناسـب يارامترهـاى

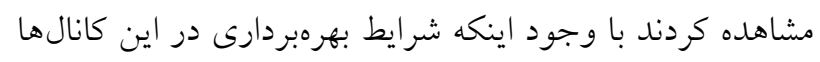

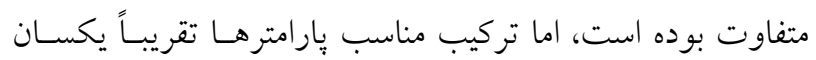

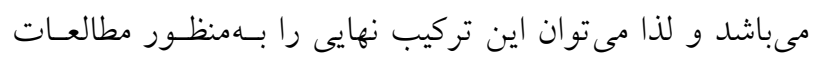

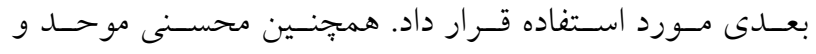

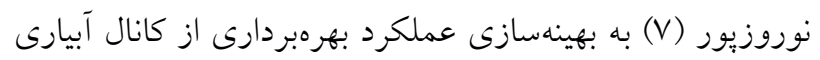

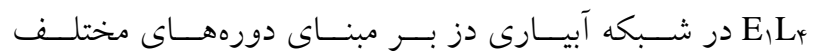

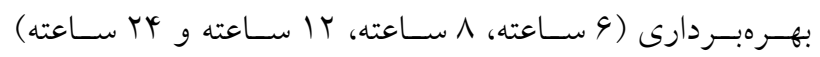
يرداختند. نتايج اين تحقيق به انتخاب دوره بهرهبردارى ^ ساعته

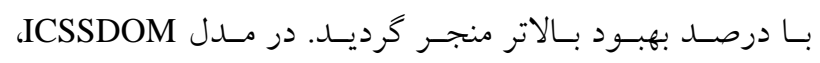

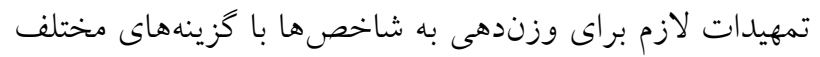

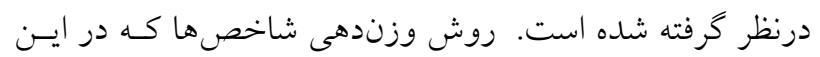

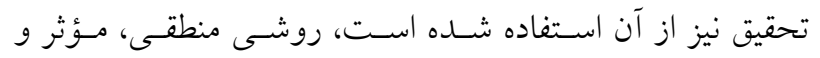

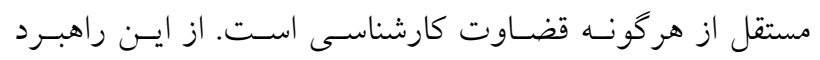

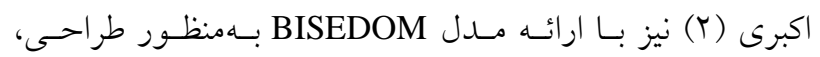

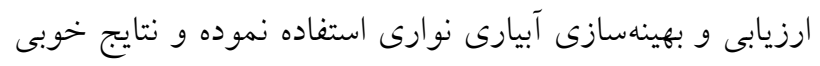
بهدست آورده است. هدف اين تحقيق آزمون هرجه بيشتر روش بيشنهادى وزن اند

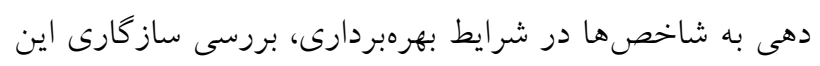

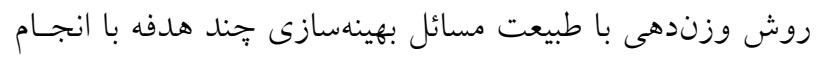

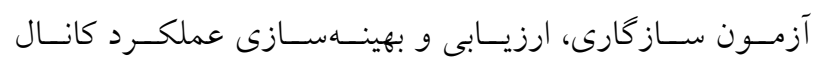
S-L-Rه

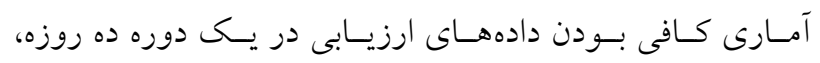
اعتبارسنجى مدل با روش رياضى مجانب و يِيدا كـردن بهتـرين حالت ممكن براى تنظيم دريجهها و سازههاى كنترل مى باشد.

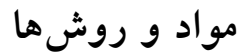

تابع هدف، روش وزندهى و گزينهاى روش وزندهى

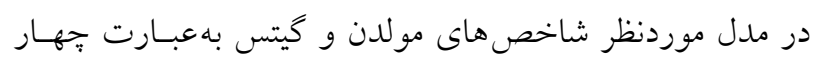
معيار كفايت (متوسط نسبت دبى تحسويلى بـه دبسى مـورد نيساز

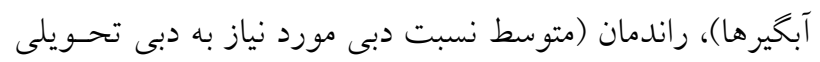

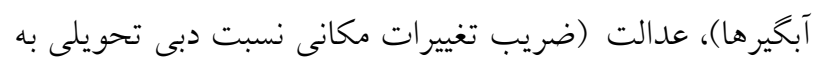

عدم بازده مورد انتظار اغلب شبكههاى آبيارى لـزوم ارزيسابى و

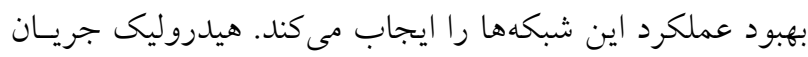

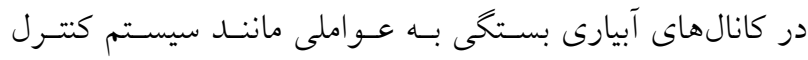

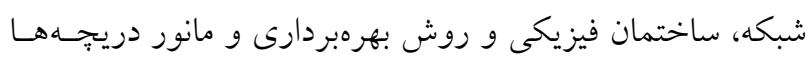

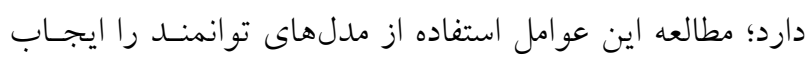

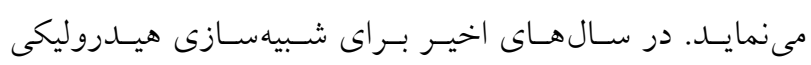

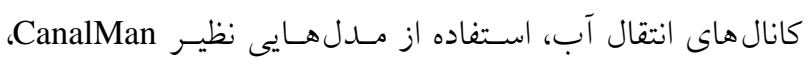
SIC ،OPDM ،PAIS ISIS ،MIKE ،HEC-RAS ،SOBEK

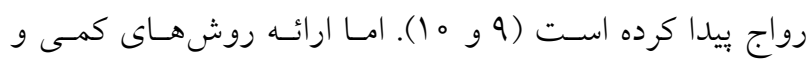

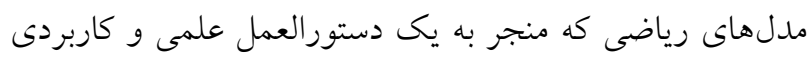

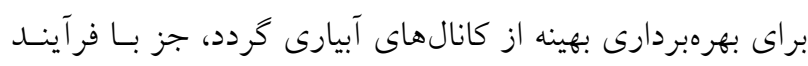

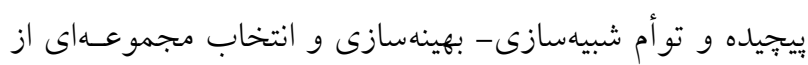
شاخصهاى عملكرد مناسب امكانيذير نيستــ در ايسن راستـا

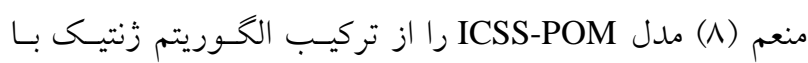

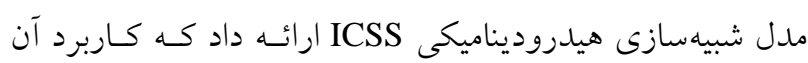

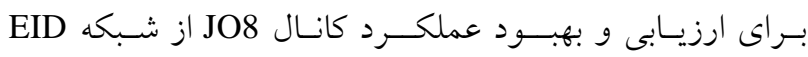

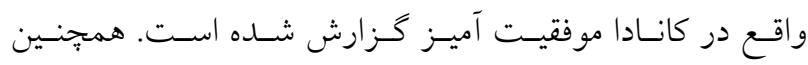

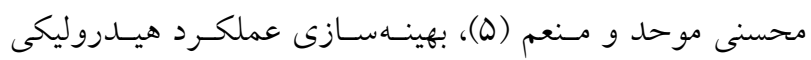

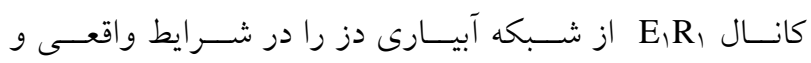

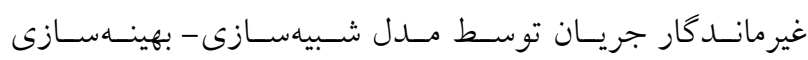

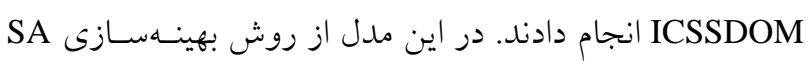

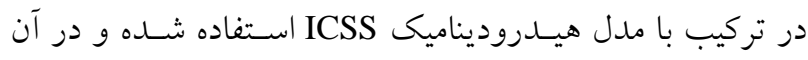

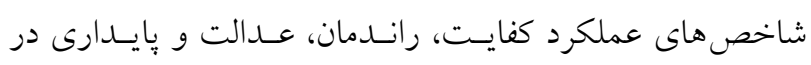

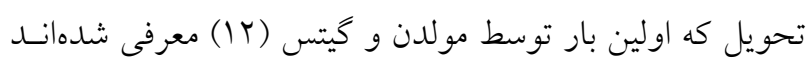
به كار رفته است. در اين مدل در يكى دوره تحويل برحسب نيل نياز

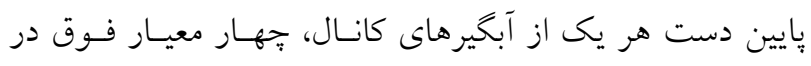

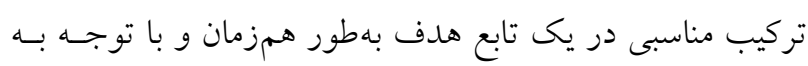

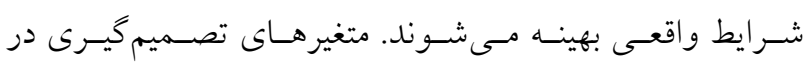

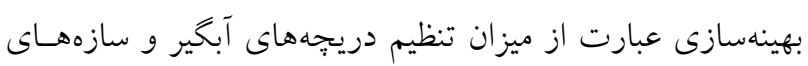

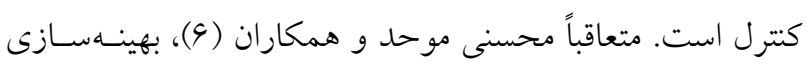

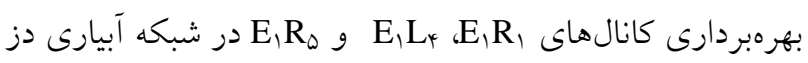


[r] [بملكرد موجود شـاخص - عملكــرد ايسـهآل شـاخص|

$$
\text { بتانسيل بهبود آرمانى }
$$

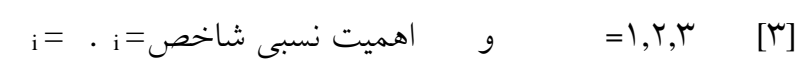

$C_{i}=1+\beta_{i}=\gamma_{i} \theta+1$

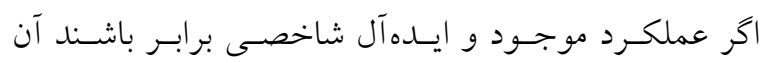

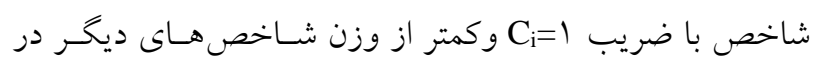

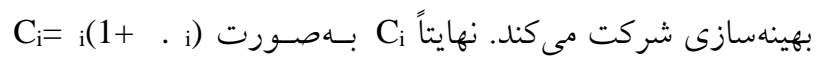

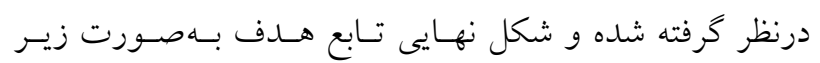

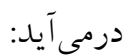

$\mathrm{FF}_{\min }=\lambda_{1}\left(1+\theta \gamma_{1}\right)(1-\mathrm{MPA})+\lambda_{r}\left(1+\theta \gamma_{r}\right)(1-\mathrm{MPF})+$ $\lambda_{\mu}\left(1+\theta \gamma_{r}\right) \mathrm{MPE}+\lambda_{\psi}\left(1+\theta \gamma_{\psi}\right) \mathrm{MPD}$

با صفر قرار دادن خ مئسوان شاخصسى را كـه در وضـعيت

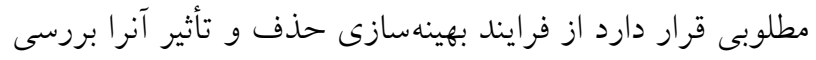

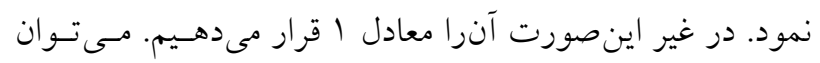

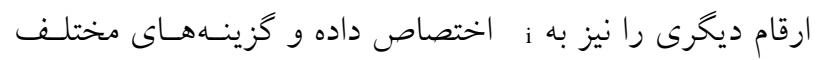

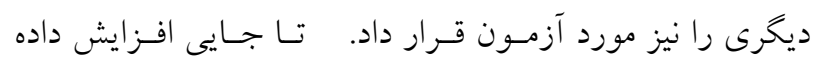

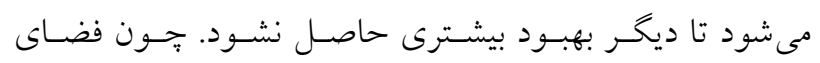

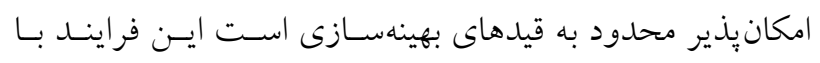
رايانههاى برسرعت در زمـان كمسى قابـل انجـام اسـت. متعاقبـاً

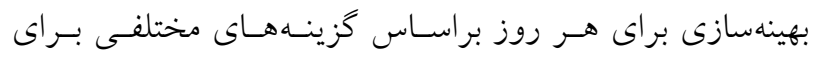
ضرايب وزنى به شرح زير صورت كرفت.

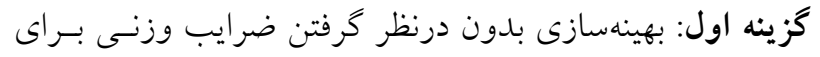

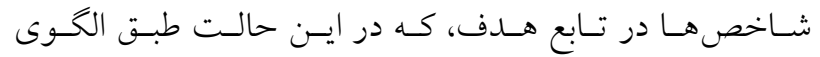

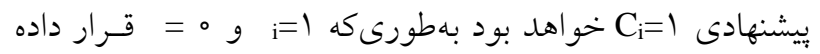
مى شود. كزينه دوم: ضريب وزنى هـر شـاخص معـادل يتانسـيل بهبـود

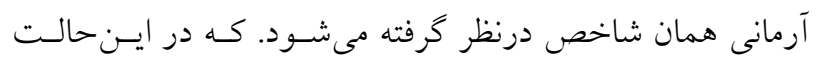
بل بورى كه $C_{i}=\gamma_{i}$

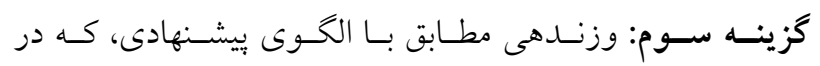

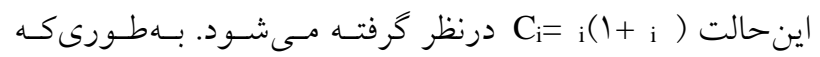

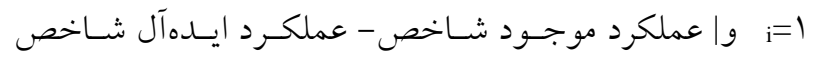
$\ldots, r, r, l=\theta, \gamma_{i}=1$
دبى مورد نياز آبخيرها) و بِايدارى در تحويل (ضـريب تغييـرات

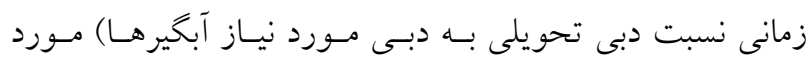

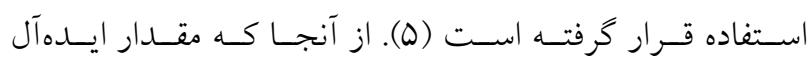

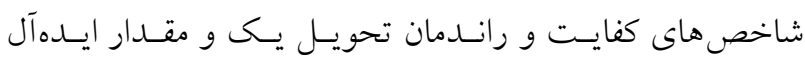

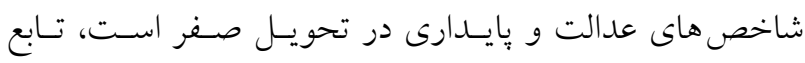

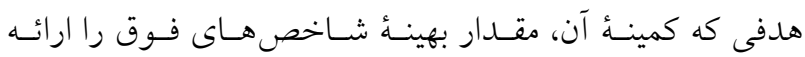
مى دهد بهصورت زير است: $\begin{aligned} \mathrm{FF}_{\min } & =\mathrm{C}_{1}(1-\mathrm{MPA})+\mathrm{C}_{r}(1-\mathrm{MPF}) \\ & +\mathrm{C}_{r} \mathrm{MPE}+\mathrm{C}_{r} \mathrm{MPD}\end{aligned}$

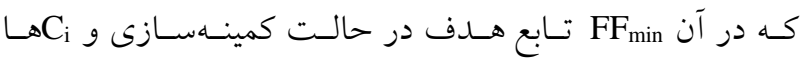

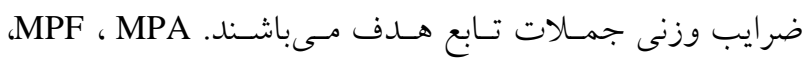

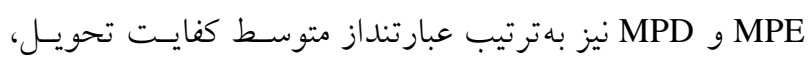

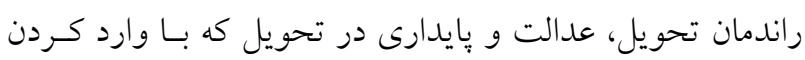
دبى مورد نياز زير دست هر آبحير، دبى واقعى تحويلى به كانال،

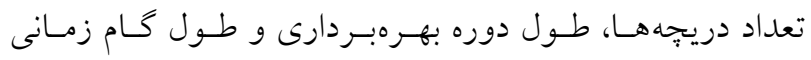

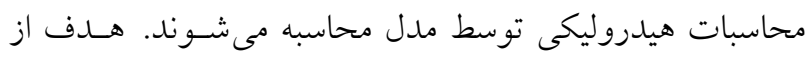

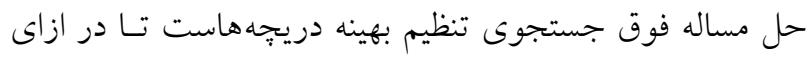
آن مجموع (وزنى) انحر اف هر شاخص نسبت به مقدار ايـدهآل

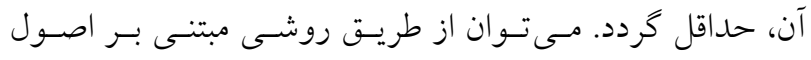

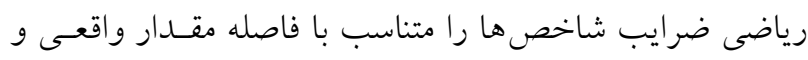

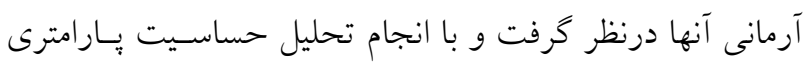

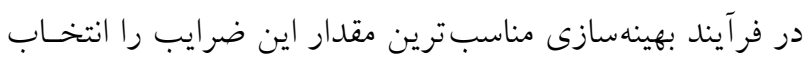
نمود. براى اين كار مى توان براى شاخص يا شاخصهايى كه در وضع موجود عملكرد بدترى دارند اهميت (وزن) بيشترى قائسل شد و نتيجه را با ساير حالات مقايسه كرد. بهاينمنظور ضـرايب

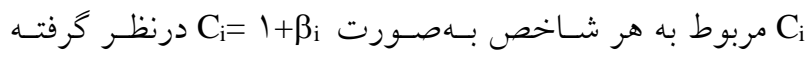

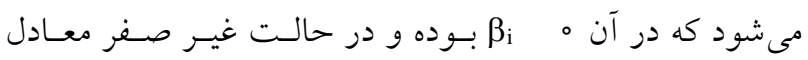

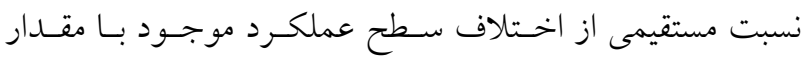

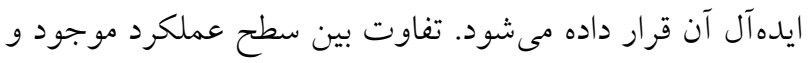

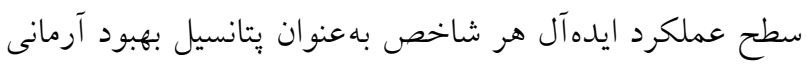

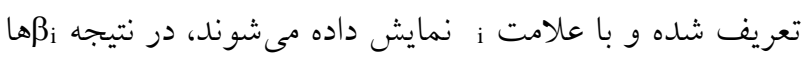

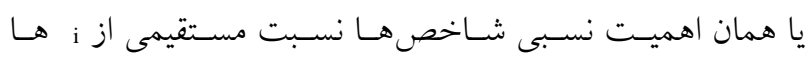
مىباشند و روابط زير بين اين پيارامترها برقرار است: 
جدول ا. برنامهُ تحويل آب وضع موجود براى يكى تقويم ده روزه از آمار كانال S-L-R (ليتر بر ثانيه)

\begin{tabular}{|c|c|c|c|c|c|c|c|c|c|c|c|c|c|}
\hline \multirow{2}{*}{ تار دريجه } & \multicolumn{2}{|c|}{$R_{0}-\Lambda$} & \multicolumn{2}{|c|}{$\mathrm{R}_{0^{-}} 9$} & \multicolumn{2}{|c|}{$\mathrm{R}_{\Delta^{-}} \mid r A$} & \multicolumn{2}{|c|}{$\mathrm{R}_{0^{-}}-10$} & \multicolumn{2}{|c|}{$\mathrm{R}_{\Delta^{-}}-11$} & \multirow{2}{*}{ جماز } & \multirow{2}{*}{ تحويل } & \multirow{2}{*}{ اختلاف } \\
\hline & نياز & تحويل & نياز & تحويل & نياز & تحويل & نياز & تحويل & نياز & تحويل & & & \\
\hline 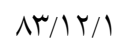 & $r 19 / 0$ & 110 & $\Delta V$ & Q. & VT & 90 & $\Delta V$ & $\psi_{0}$ & $\Lambda \kappa / q$ & Vo & $4 q \circ / 4$ & roo & $-11 / 4$ \\
\hline$\Lambda \Gamma / \Lambda r / r$ & $r 19 / 0$ & 110 & $\Delta V$ & Q. & VT & 90 & $\Delta V$ & $\psi_{0}$ & $\Lambda \kappa / q$ & 90 & $\varphi q \circ / 4$ & $r q_{0}$ & $-r \circ / \Delta$ \\
\hline$\Lambda \Gamma / \Lambda r / \mu$ & $r 19 / 0$ & 110 & $\Delta V$ & Q. & VT & 90 & $\Delta V$ & $\psi_{0}$ & $\Lambda \psi / q$ & 90 & $4 q \circ / 4$ & $r q_{0}$ & $-r \circ / Q$ \\
\hline$\Lambda \Gamma / \Lambda T / \varphi$ & $r 19 / \Delta$ & 110 & $\Delta V$ & Q. & VT & 90 & $\Lambda r / \Delta$ & ro & $\Lambda \kappa / q$ & 90 & $019 / 9$ & rq. & $-r \phi / 。$ \\
\hline$\Lambda r / \Lambda r / \Delta$ & $r 19 / 0$ & 110 & $\Delta V$ & $r_{0}$ & VQ & 90 & $\Lambda \Gamma / \Delta$ & $\Delta_{0}$ & $\Lambda \kappa / q$ & $\Delta_{0}$ & $019 / 9$ & rvo & $-r N / \Lambda$ \\
\hline$\Lambda \Upsilon / \Lambda r / \varphi$ & $r 19 / 0$ & 110 & $\Delta V$ & $r_{0}$ & Vo & 90 & $\Lambda \Gamma / \Delta$ & Q. & $\Lambda \kappa / q$ & 90 & $019 / 9$ & $r_{\Lambda}$ 。 & $-r \varphi / 9$ \\
\hline$\Lambda \Gamma / \Lambda Y /$ & $r 19 / 0$ & 110 & vq & $\mu_{0}$ & VQ & 90 & $\Lambda \Gamma / \Delta$ & Q. & $\Lambda \psi / q$ & 90 & $019 / 9$ & rی。 & $-r q / 9$ \\
\hline$\Lambda \Gamma / \Lambda r / \Lambda$ & $r 19 / 0$ & 110 & vq & 90 & VQ & 90 & $\Lambda \Gamma / Q$ & Q. & $\Lambda \psi / q$ & 90 & $019 / 9$ & 410 & $-T Y / T$ \\
\hline$\Lambda r / \Lambda r / q$ & $r / 9 / \Delta$ & 110 & $\Lambda V$ & 90 & Vo & 90 & $\Lambda \Gamma / \Delta$ & Q. & $109 / 9$ & 90 & $\Delta V Y / q$ & 410 & $-r \Lambda / r$ \\
\hline$\Lambda r / T r / \Lambda 。$ & $r 19 / \Delta$ & 110 & $\mid K Y / 4$ & 100 & Vo & Vo & $\Lambda r / \Delta$ & 90 & $109 / 9$ & 1. & $991 / \pi$ & 490 & $-r \Delta / q$ \\
\hline
\end{tabular}

آزمون ساز كارى براى روش ييشنهادى وزندهى

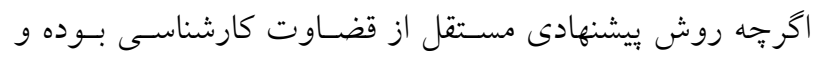

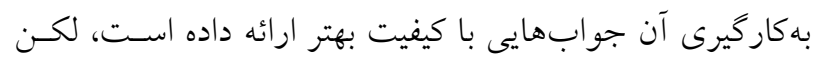
جهت اطمينـان بيشـتر و بررسى ايسن كـه آيـا روش مـوردنظر

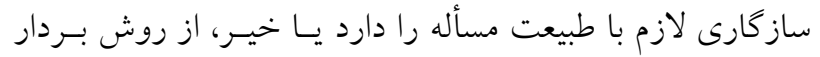

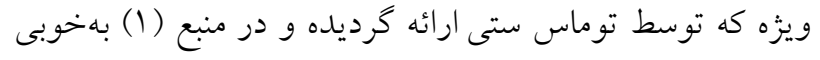

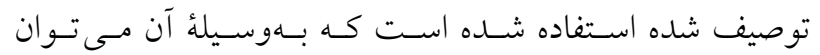
قضاوتهاى تصميم گيرنده در وزندهى به شاخص ها را سنجيد.

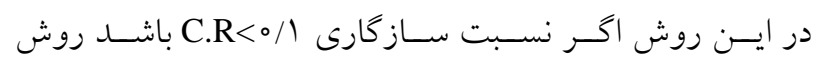

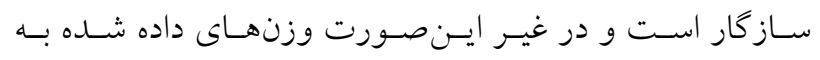
شاخص ها بايستى طبـق روش تشـريح شـــه در منبـع مـذكور

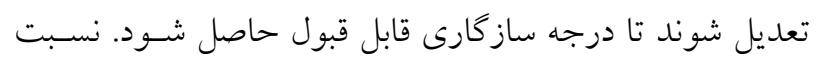
سـاز كارى عبـارتاسـت از C.R = كـه در آن شـاخص سازگارى از رابطه زير محاسبه مىشود:

C.I $=\frac{\lambda \max -n}{n-1}$

در رابطه فوق n تعـداد شـاخصهـا بـوده و بردار ويزه است كه از رابطه زير قابل محاسبه است: $\lambda \max =\left(\sum_{\mathrm{i}=1}^{\mathrm{n}} \mathrm{a}_{\mathrm{ij}} \cdot \mathrm{w}_{\mathrm{j}}\right) / \mathrm{w}_{\mathrm{i}}$
مشخصات كانال انتخابى براى مطالعه موردى

كانال S-L-R منشعب از كانـال El ذوزنقهاى است كه در منطقه سبيلى شبكةُ آبيارى دز واقع شــده

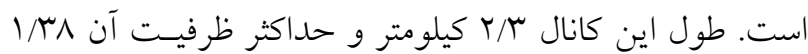

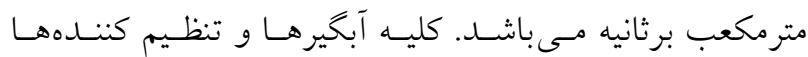

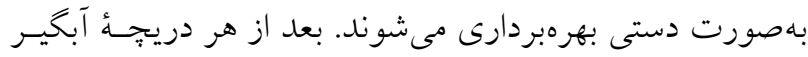

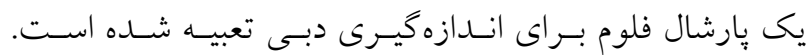

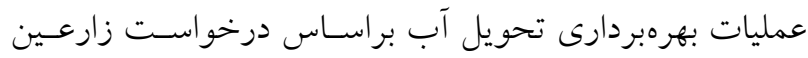

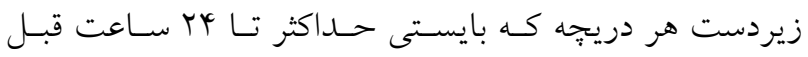

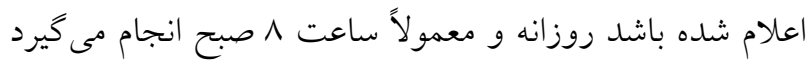

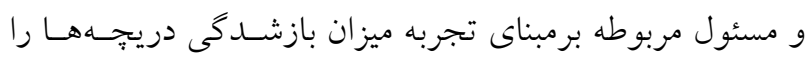

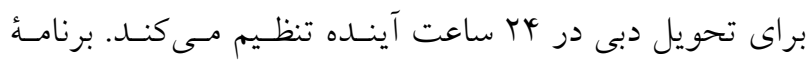

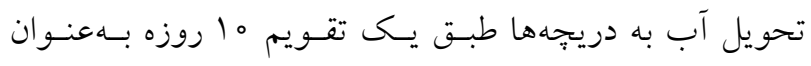

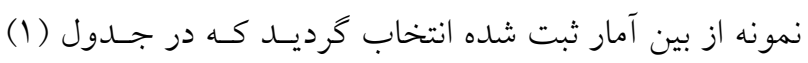

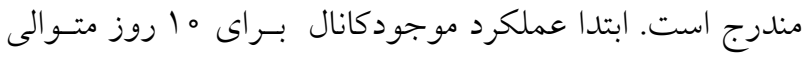

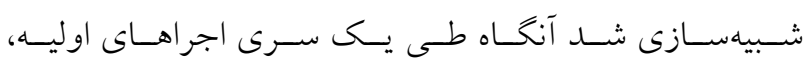

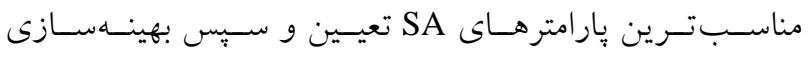
عمليات بهرهبردارى از كانال در شرايط واقعى بــراى هـر روز توسط مدل انجام گرفت. 
جدول r. مقادير شاخص تصادفى برحسب تعداد شاخصها (1)

\begin{tabular}{|c|c|c|c|c|c|c|c|c|c|c|c|}
\hline 11 & 10 & 9 & $\wedge$ & v & 9 & 0 & $r$ & r & r & 1 & تعداد شاخصها \\
\hline $1 / 01$ & $1 / Q V$ & $1 / 4 \theta$ & $|/ 4|$ & $1 / T r$ & $1 / Y^{4}$ & $1 / 1 T$ & $\circ / 9$ & $\circ / \Delta \wedge$ & 。 & 。 & R.I \\
\hline
\end{tabular}

ب h - ب نصف طول فاصله اطمينان حساب مى شود. ه- از رابطـه مقايسه مىشـود. اخــــــــن دو مقــدار تقريبـاً يكســان بـوده ويـا اختلاف قابل اغماض داشته باشــد مســأله حـل اسـت، در غيـر اينصورت n ديخرى فرض شده والخوريتم تكرار مىشود و يـا

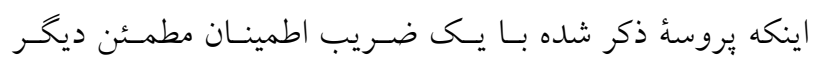
مجدداً بررسى مى كردد.

\section{روش مجانب بهعنوان ابزار اعتبارسنجى مدل} از آنجا كه در الكوريتمهاى بهينهسازى تصادفى بـهـ شـرط آنكـهـ الكوريتم در دام نقاط محلى نيفتــد بـا افـزايش تعـداد تكرارهـا احتمال بهتر شدن جوابها هست و نظر به اينكه الخـوريتم توانايى خروج از دام نقاط بهينه محلى را دارد، لـذا در تئسورى ثابت شده كه اخر زمان اجراى الكوريتم به سمت بينهايـت ميـل كند جوابها نيز با احتمال صد در صد به سمت بهينه سراسرى همخرا خواهد شد (11). در اين مقاله از ايسن خاصسيت اسـتفاده شده و با يك روش ابتكارى بهينه سراسرى تخمين زده مى شود. در اين روش مقادير بهبود يافته تـابع هــف در دامنـه انتخـابى بهاعنوان متغير مستقل و تعداد تكرارهاى يذّيرفته شده بـهنعـوان متغير وابسته، با مدل تـابع معكـوس در رگرسـيون سـاده مــل لهل مىشود و با رسيدن به يك ضريب همبستخى مورد قبول، مقادير ض و a a

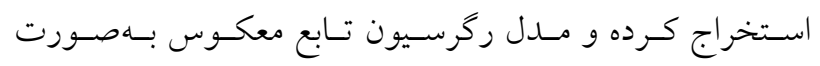
ا تشكيل مىشود. در اين رابطـه FF / N=a+b(FF) هدف و N تعداد تكرارهاى يذيرفته شده مىباشد. حال در ازاى خط مجانب، مقدار تابع معكوس را محاسـبه كـرده و بـهـعنـوان

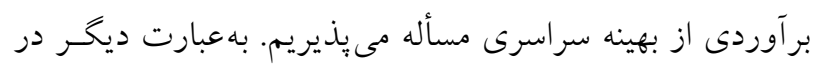
اين روش مقدار تابع هدف در ازاى تكرارهاى بينهايت تخمسين
اخر اوزان خام و نرمال نشــه شـاخص هــا كـهـ بـا قضـاوت تصميم گيرنده در يك مقايسه زوجى تعيين شده عبـارت باشـند

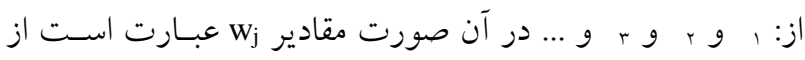
مقادير نرمال شده V ها و مقادير a dij $a_{11}=\frac{\gamma_{1}}{\gamma_{1}}, a_{1 r}=\frac{\gamma_{1}}{\gamma_{r}}, a_{1 r}=\frac{\gamma_{1}}{\gamma_{r}}, \ldots, a_{1 n}=\frac{\gamma_{1}}{\gamma_{n}}[\Lambda]$ مقدار R.I نيز عبارت اسـت از يـك شـاخص تصـادفى كـه

برحسب تعداد شاخص ها از جدول(Y) استخراج مىشود (1).

بررسى آمارى كافى بودن دادههاى ارزيابى در اين كار تحقيقى از يك آمار ده روزه استفاده شده اسـت. امـا

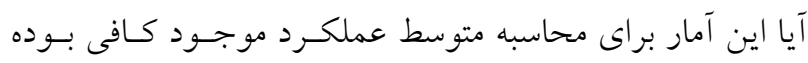
است يا خير؟ براى ياسخ بـهـ ايسن سـوال نـاگزير بــه اسـتفاده از روش هاى آمارى مطمئن بــراى ارزيـابى طـول دوره مسىباشـيم. حجم نمونه لازم از جامعه براى نيل به نصف فاصله اطمينـان با ضريب م-1 و با تخمين واريانس (S) از رابطـه زيــر قابـل محاسبه است (r): (r) $\mathrm{n}=\frac{\mathrm{t}^{r} \cdot \mathrm{s}^{r}}{\mathrm{~h}^{r}}$ كه در آن t كوانتيل توزيع t- استيودنت بوده و از جـداول مربوطه باتوجه به درجـهـ آزادى و ضـريب اطمينـان مـورد نظـر استخراج مىشود. براى محاسبه حداقل حجم نمونه لازم كـه در اينجا همان تعداد روزهاى مورد استفاده قـرار كرفتـه مسىباشــ، برحسب يك ضريب اطمينان مشـخص از الخـوريتم سـادهُ زيـر

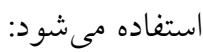
ا- ابتدا مقدارى براى n فرض مىشود؛ r- براساس n فرضى و با ضريب اطمينان مورد نظر t از جـدول مربوط به توزيع t -استيودنت استخراج مىشود. r- فاصله اطمينان براساس اطلاعات موجود محاسبه مىشود. 
جدولr. نتايج بهينهسازى براساس گزينه هاى سه گانه و حالت موجود براى تقويم ده روزه انتخابى

\begin{tabular}{|c|c|c|c|c|c|c|c|c|c|c|c|c|}
\hline \multicolumn{4}{|c|}{ عملكرد يِايدارى در تحويل } & \multicolumn{4}{|c|}{ عملكرد عدالت در تحويل } & \multicolumn{4}{|c|}{ عملكرد كفايت در تحويل } & \multirow{3}{*}{ تاريخ } \\
\hline 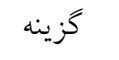 & 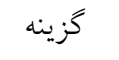 & 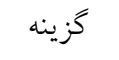 & حالت & 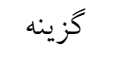 & 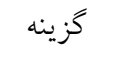 & 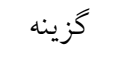 & حالت & 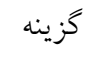 & 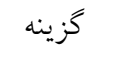 & 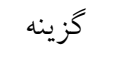 & حالت & \\
\hline سوم & دوم & 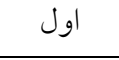 & موجود & سوم & دوم & اول & موجود & سوم & دوم & 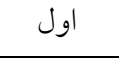 & موجود & \\
\hline ०००ᄉr &.$/ 0100$ &.$/ 0100$ & optra & .10091 & ./1TQ &.$/ 01$ L & $\circ / 0 \vee 9$ & - /NIYA & o/NIVA & -/NIVA & $\circ / \Lambda \circ 94$ & $\Lambda r / \Lambda T / \Lambda$ \\
\hline ./००ाr & $\circ / \circ \circ \mu_{0}$ & $\circ / \circ \circ \mu_{0}$ &.$/ 11 T \Delta$ & $0 / 0009$ & O/OOKY & O/OOLY & ०/०१९Y & - /VQDY & ०/V৭৭^ & -/V৭৭^ & -/V^ৎ9 & $\Lambda r / \Lambda T / r$ \\
\hline $0 \% 004$ & $\circ / \circ \circ \circ \wedge$ & $\circ / \circ \circ \circ \wedge$ &.$/ 11 T \Delta$ & $\circ / \circ \circ \circ \mathrm{V}$ & $0 / 0009$ & $0 / 0009$ & ०/०१९Y & $\circ / V 901$ & -/VQDY & - /VQDY & -/V^G9 & $\Lambda r / T / \mu$ \\
\hline $0 / 019 x^{k}$ & $\circ / \% q_{0}$ & $\circ / 0490$ &.$/ 1940$ &.$/ 01 \wedge 0$ & - $0 Y \Delta Q$ & - 0 Y OA & $\circ / K \circ 91$ & - NYAR & - NG94 & - NGG4 & -/VTAY & $\Lambda r / \Lambda T / \mathcal{K}$ \\
\hline \%ookt & ००Yl० & $\circ / \circ \circ \mathrm{VV}$ & $0 /|V| F \mid$ & oo० & O/OYMI & $\circ / \circ \circ 01$ & $0 / Y 009$ & $\circ / N I Y q$ & $\circ / V \backslash \wedge \Delta$ & $\circ / V 1 \circ 4$ & -1990r & $\Lambda r / \Lambda r / \Delta$ \\
\hline$\% \circ \circ \mathrm{V}$ & $\circ / \circ \circ \Delta Y$ & $\circ / \circ \circ \circ \mathrm{V}$ & - IYAQ & 010009 & $0 / 0009$ & $0 / 0009$ & ०/1199 & $\circ / V \mu \circ \Lambda$ & ONMYY & ०NMII & $\circ / 9 \wedge 9 \circ$ & $\Lambda \Gamma / \Lambda T / 9$ \\
\hline $0 / 01 k y$ & OOYYG &.$/ 0194$ & $\circ / \Lambda \Lambda 。$ &.$/ 0100$ & O/OYKY &.$/ 01 \mathrm{VV}$ & OTYYYY & $\circ / N \circ \Delta \circ$ & $\circ / \mathrm{V} 1 \circ \mathrm{V}$ & $\circ / V \circ \wedge \Delta$ & $.1909 \mathrm{~V}$ & $\Lambda \Gamma / \Lambda T / V$ \\
\hline \%००पा & $0 / 0091$ & o/o० kV & - / lor & ०००YV & $0 / 01 T 9$ & $\circ \circ \mathrm{VQ}$ & O/YYYA & - NDSI & -/VQAR & -NQGA & -NMGY & $\Lambda r / \Lambda T / \Lambda$ \\
\hline $.019 \mathrm{~V}$ & $0 / 0409$ & ०/०YV。 & - TQDQ & OOYYA & \%OTL & ortys & ०/VYA & $\circ / N \backslash \wedge \Delta$ & $0 / V 419$ &.$/ 2191$ & 019949 & $\Lambda r / \Lambda r / q$ \\
\hline.$/ 010 F$ & $\circ / \circ \Delta \Delta V$ &.$/ 490$ & - MrqV & \% TQG & $\circ / \circ \vee \wedge I$ & ०/OYIT & $\circ / \backslash \wedge 9 \vee$ & -NYAD & -NYYAD & -NYADQ & - NYAAD & $\Lambda \mu / \Lambda T / l \circ$ \\
\hline$\circ \% \circ \wedge \mathrm{V}$ & o/ &.$/ 014 V$ &.$/ 904$ & 010104 & O/OTGY &.$/ 0|V|$ & ./94 & -NOTG & $\circ / V Q \wedge q$ & $\circ / V Q \Delta \circ$ & $\circ / N T_{1}$ & متوسط \\
\hline $94 / V$ & $\Lambda V / I$ & $91 / 1$ & --- & $9 \pi / \Lambda$ & $\Lambda \& / \mu$ & $19 / 0$ & --- & $\mu / 。$ & $\mu / \Lambda$ & $\mu / \mu$ & --- & بهبود (\%) \\
\hline
\end{tabular}

شبيهسازى شـرايط موجـود بــراى دوره ده روزه در جــدول (r) آمده است. از آنجا كه در تمامى روزهاى دوره انتخابى دبى تحويلى كمتـر از دبى موردنياز بوده، بــيهى اسـت شـاخص رانـدمان هــم در حالت موجود و هم وضعيت بهينه مقدارى برابر يك داشته كـه بههمين دليل اين شاخص در جداول منظور نشده اسـت. قابـل ذكر است كه يك بودن شاخص راندمان دليل بر توزيع مناسب دبى نمىباشد. در جنين مواردى كه دبى تحويلى كمتـر از نيـاز اعلام شده است اخر ناعادلانه و نايايدار هم توزيع شود بههـيج وجه صـحيح نبـوده و نارضـايتى زارعسين را بـهدنبـال خواهـد داشت. جنانجه از دو رديف آخر جـدول (r) مشـخص اسـت شـاخصهــاى عـدالت و وِايــارى در حالـت بهينــه تفــاوت جشم گيرى با حالت موجود نشان مىدهند. شاخص كفايت نيز كه در وضع موجود تقريباً مناسـب اسـت بـاز هــم بهتـر شــده باتوجه به جند هدفى بودن مسئله بهينهسازى و اثـر متقـابلى
زده شده و با تابع هدف حاصل از بهينهسازى مقايسه مىشـود و مى تواند ابزار خوبى براى اعتبارسنجى نتايج مدل باشد (4) جون هيج معيار واقعى مناسب ديخرى وجود ندارد. $\operatorname{Lim}_{N \rightarrow \infty} 1 / N=a+b(F F)=。 \Rightarrow$ FFglobal $\approx-a / b$ If $: \mathrm{T} \rightarrow \infty$ then $: \mathrm{N} \rightarrow \infty$

تعيين بهترين حالت ممكن براى بازشدگى دريجهها

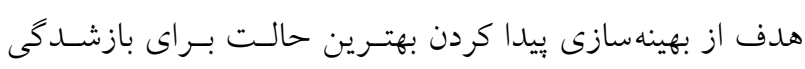

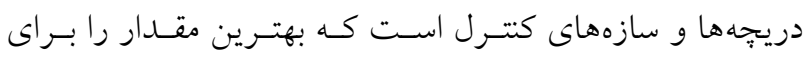
شاخص هاى عملكرد بهدست مى دهد. لذا از فايل خروجى مدل

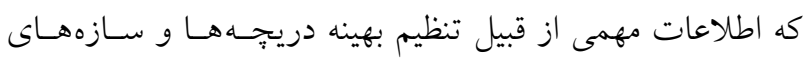
كنترل، دبى مورد نياز و دبى تحويلى در شرايط بهينـه و مقـادير بهينه شاخص هاى عملكرد گزارش مىشود، استفاده مى كنيم.

\section{نتايج و بحث} تحليل گزينههاى روش وزندهى نتايج بهينهازى كزينـههـاى ســـانـه و نيـز نتسايج حاصـله از 

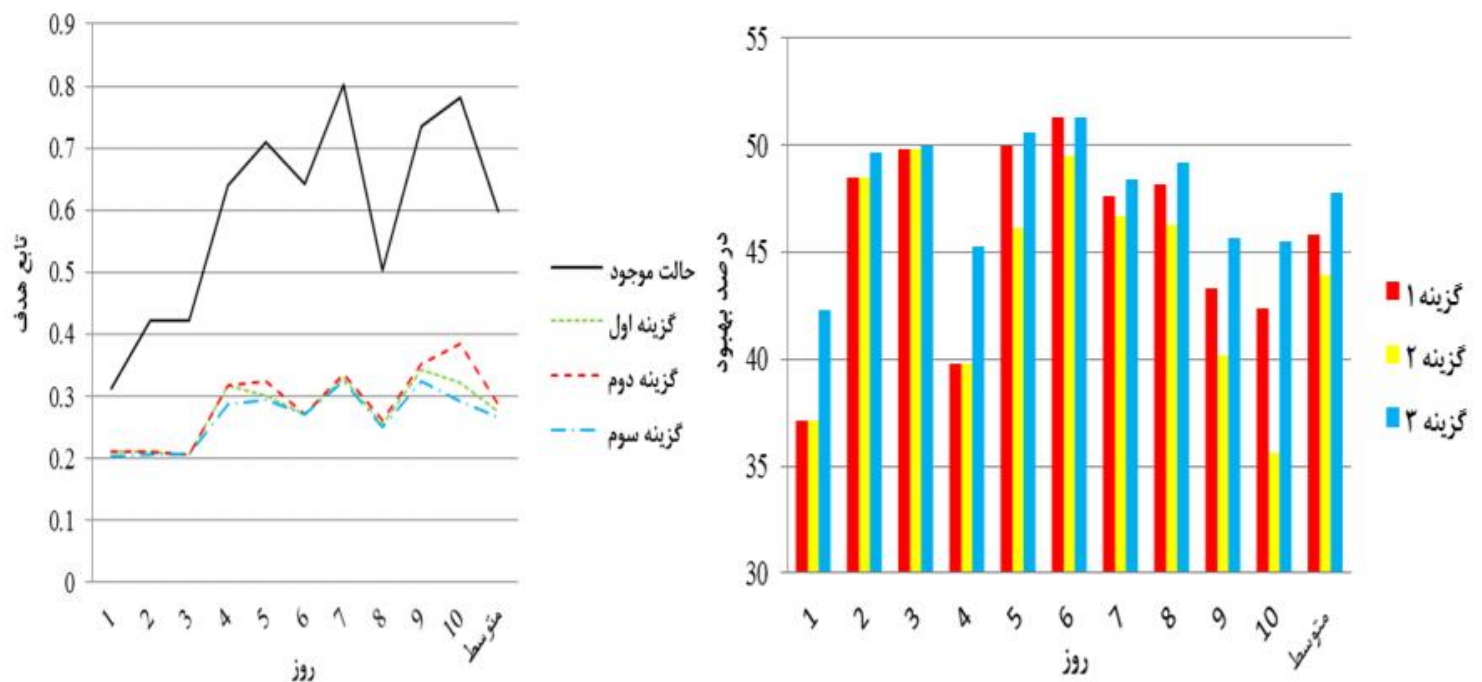

شكل ا. نمودارهاى روزانه تابع هدف و درصد بهبود در گزينهاى مختلف

جدول أ. محاسبة ضرايب وزنى جملات تابع هدف در گزينهُ دوم و سوم

\begin{tabular}{|c|c|c|c|c|}
\hline $\mathrm{C}_{\mathrm{i}}$ & 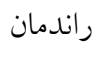 & 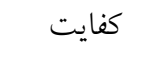 & 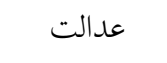 & يايدارى \\
\hline متوسط عملكرد موجود براى دوره ده روزه & 1 & $\circ / N$ & $0 / 19$ &.$/ \mathrm{V}$ \\
\hline عملكرد ايدهآل & 1 & 1 & 。 & 。 \\
\hline يتانسيل بهبود آرمانى & 。 & $0 / T V$ & $0 / 19$ & $\circ / \mathrm{V}$ \\
\hline ضريب وزنى در گزينه دوم & $\circ$ & $\circ / T V$ & $0 / 19$ & $\circ / \mathrm{V}$ \\
\hline ضريب وزنى در گزينه سوم & 1 & $1+\circ / T V \theta$ & $1+0 / 19 \theta$ & $1+0 / 1 \vee \theta$ \\
\hline
\end{tabular}

در تمامى روزها بهبود جشمى گيرى داشته است. همانطوركه كفته شد ضرايب شاخص ها در گزينه اول برابر يك، در گزينه دوم برابر بتانسيل بهبود آرمانى و در گزينه سـوم

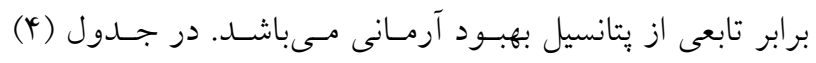

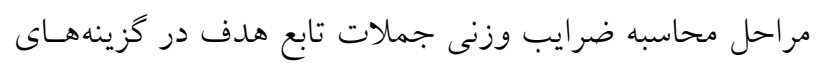
دوم و سوم آمده است. در كزينه سوم يارامتر $\theta$ در تـابع هــدف براى هر روز با اسـتفاده از تحليـل حساسـيت تعيـين مسىشـود

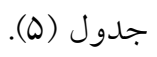

نتايج آزمون سازكارى براى روش بيشنهادى وزندهى شرط ساز گارى براى گزينههاى دوم و سوم كه بهينهسازى بـراى اي كل دوره ده روزه انتخابى انجام شده بررسى كرديد. باتوجـه بـهـ

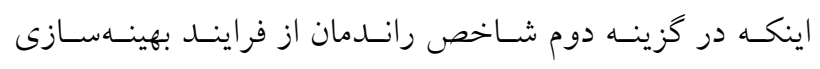

كه شاخصها بر هم دارند، قضاوت و تصـميم گيـرى نهايى در مورد مناسبترين حالت ضرايب وزنسى در نهايـت بايسـتى بـر مبناى درصد بهبود متوسط تمـامى شـاخصهـا صـورت گيـرد. بهنوان مثال در گزينـه دوم شـاخص كفايست بيشـترين درصـد بهبود را نسبت به ساير گزينهها نشان مىدهد؛ درحالى كه مقادير درصد بهبود شاخص هاى عدالت و يايدارى در گزينه دوم كمتر

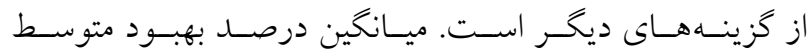

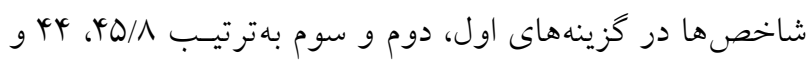

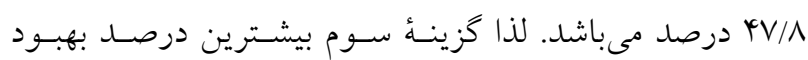

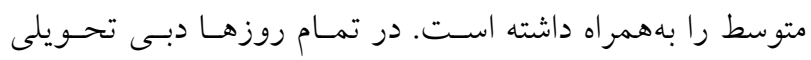

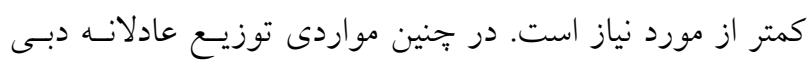
اهميت ويزهاى دارد. در شكل (1) نمودارهاى روزانه تابع هدف

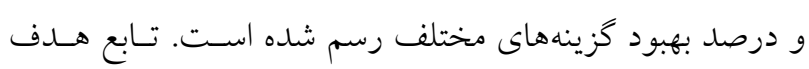


جدوله. تعيين يارامتر 0 براى هر روز از دورة آمارى با استفاده از تحليل حساسيت

\begin{tabular}{|c|c|c|c|c|c|c|c|c|c|c|}
\hline$\Lambda r / \Lambda T / \Lambda \circ$ & $\Lambda r / \Lambda T / q$ & $\Lambda T / \Lambda \mathrm{r} / \Lambda$ & $\Lambda T / \Lambda / \nu$ & $\Lambda T / \Lambda T / 9$ & $\Lambda T / \Lambda / \Delta$ & $\Lambda r / \Lambda T / \Psi$ & $\Lambda \Gamma / \Lambda / \mu$ & $\Lambda T / \Lambda / T$ & $\Lambda r / \Lambda T / \Lambda$ & تاريخ \\
\hline$\mu_{0}$ & $\mu_{0}$ & Yoo & 100 & 1000 & Yoo & Q. & Q. & 1.0 & $\Lambda^{\circ}$ & $\theta$ \\
\hline
\end{tabular}

جدول 9. بررسى شرط ساز كارى ضرايب وزنى در گزينه دوم (C)

\begin{tabular}{|c|c|c|c|c|c|c|c|}
\hline C.R & R.I & C.I & $\lambda \max$ & MPD & MPE & MPA & \\
\hline \multirow[t]{2}{*}{$-1 / 4 r$} & $\circ / 0 \wedge$ & -O/NTQ & $1 / \pi 0$ & $\circ / \mathrm{V}$ & $0 / 19$ & $0 / T V$ & وزن انتخابى \\
\hline & \multicolumn{3}{|c|}{ 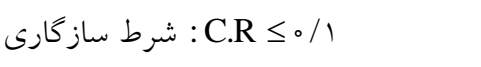 } & $0 / T \Lambda$ & $0 / T V$ & $0 / 40$ & وزن نرماليزه شده \\
\hline \multicolumn{4}{|c|}{$-1 / 4 r<0 / 1$} & $1 / 91$ & $1 / 9 \mathrm{~V}$ & 1 & $a_{1 j}$ \\
\hline
\end{tabular}

مى شود كه با تعداد روزهاى انتخابى درمورد شاخص كفايت بـا

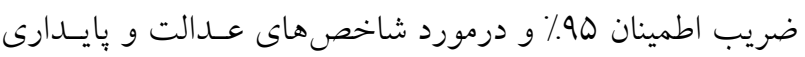

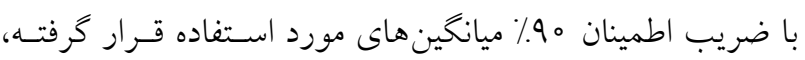

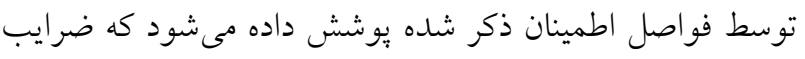

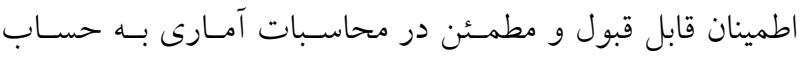

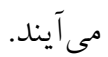

\section{نتايج اعتبارسنجى مدل با روش مجانب} از طيف انتقالهاى رو به بايين مواردى انتخاب گرديد (با توزيع

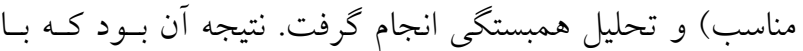
ضريب همبستكى ICSSDOM با تقريب 9 درصـد بيشتر از بهينه سراسرى حاصل از روش مجانب (بهعنـوان روش

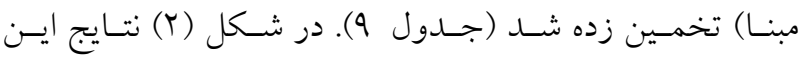
همبستكى بلصورت نمودار نشان داده شده است.

نتايج تعيين بهترين حالت ممكن براى بازشدگى دريجهها

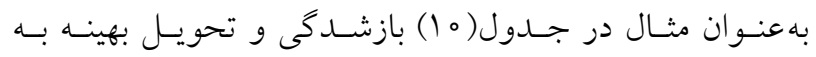

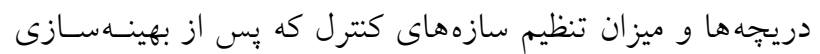
با ضرايب وزنى

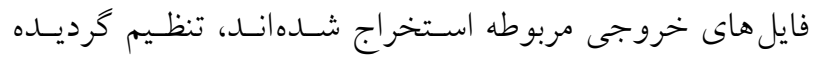

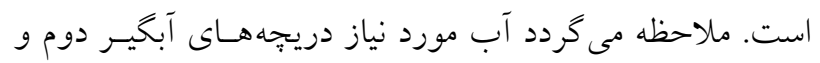

حذف شــده و بهينـهــازى سـه شاخصـه بـوده اسـت، آزمـون

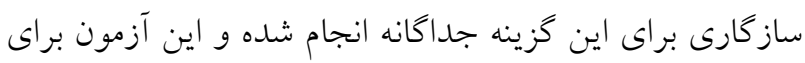

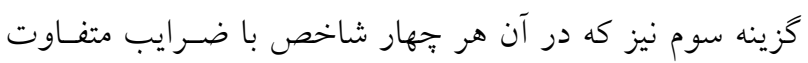

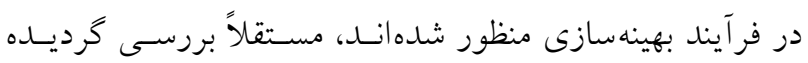

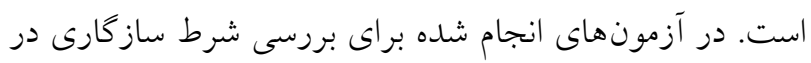

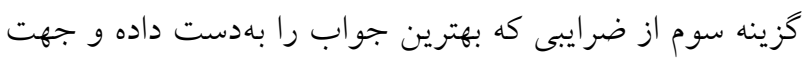
تحليل هاى مقايسهاى درنظر كرفته شدهاند، استفاده شـــه اسـت

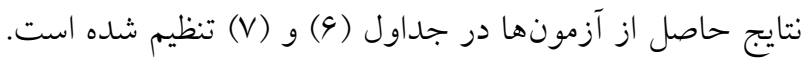

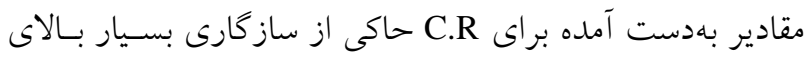
روش ييشنهادى است.

\section{نتايج بررسى آمارى كافى بودن دادههاى ارزيابى}

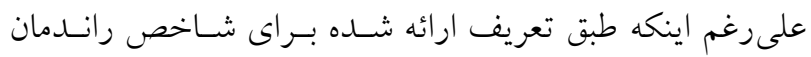
مقدار اين شاخص بهعلت كمبود آب تحويلى در تمامى روزهـا

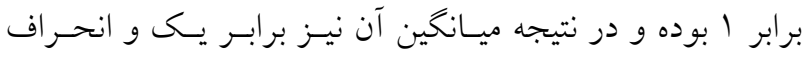

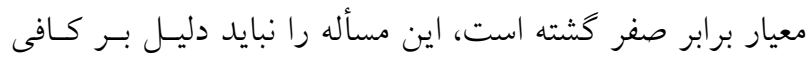
بودن طول دوره مورد نظر دانست و تعـداد روزهـا (طـول دورهٔ

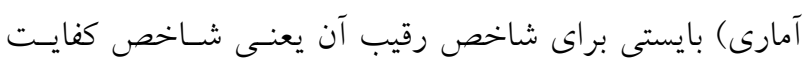

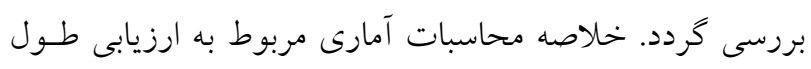

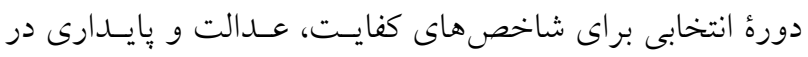

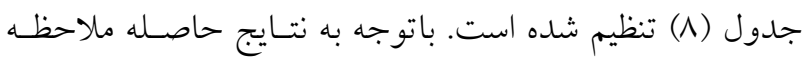




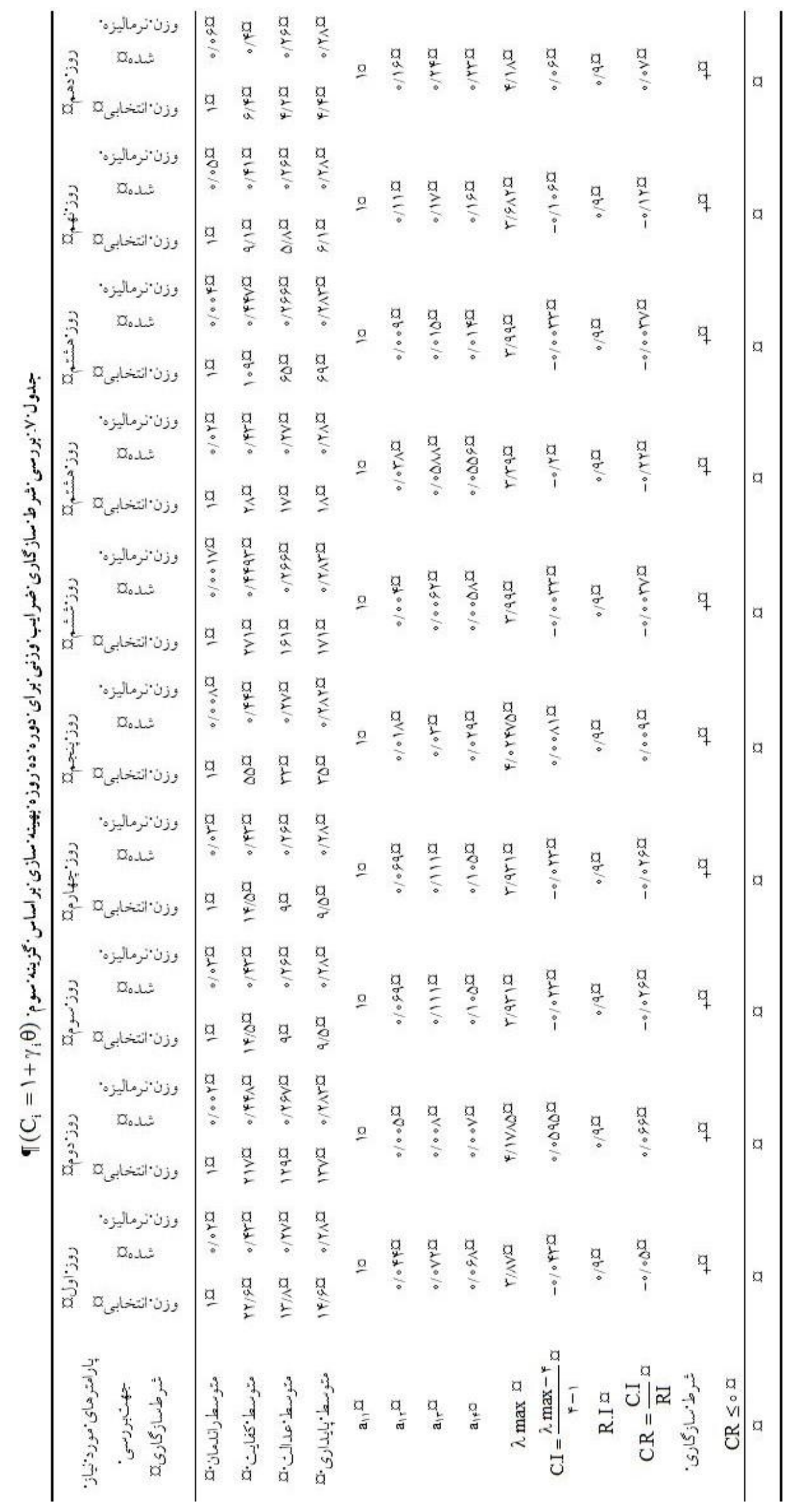


نشريه علوم آب و خاك (علوم و فنون كشاورزى و منابع طبيعى) / سال بيستم / شماره هفتادو ششم/ تابستان ههب1

جدول^ه. خلاصةٌ محاسبات آمارى مربوط به ارزيابى طول دورهٔ انتخابى

\begin{tabular}{|c|c|c|c|}
\hline شاخص & MPA & MPE & MPF \\
\hline n فرضى n & 10 & 10 & 10 \\
\hline 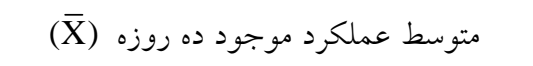 & $\circ / \mathrm{r}$ & $0 / 19$ & $\circ / 1 V$ \\
\hline انحراف معيار (s) & ०/०Drq & $\circ / 009$ & תואו \\
\hline ضريب اطمينان (م-1) & 90 & $9 \circ$ & $9 \circ$ \\
\hline$\alpha$ & $\circ / \circ 0$ & $\circ / 1$ & $\circ / 1$ \\
\hline $1-\frac{\alpha}{r}$ & $\circ / 9 \vee 0$ & $\circ / 90$ & $\circ / 90$ \\
\hline V =n - (درجئ آزادى) & 9 & 9 & 9 \\
\hline $\mathrm{t}_{1-\frac{\alpha}{r} ; \mathrm{n}-1}$ & $T / T G$ & $1 / \wedge r$ & $1 / \wedge r$ \\
\hline$\frac{\mathrm{s}}{\sqrt{\mathrm{n}}}$ & .101990 & .101199 & ०/OTGMY \\
\hline$\varepsilon=\mathrm{t}_{1-\frac{\alpha}{r} ; n-1} \cdot \frac{\mathrm{s}}{\sqrt{\mathrm{n}}}$ & ०/HVA & $\circ / 0 Y^{\prime} \mid$ & \%OHAT \\
\hline X $=\bar{X} \pm \varepsilon$ & $\circ / V \mu \pm$. & $. / 19 \pm . / \% 44$ & $. / I V \pm . / \% \wedge r$ \\
\hline بو he $=(\bar{X}+\varepsilon)-(\bar{X}-\varepsilon) / r$ & $\circ / 0 \mu$ & $\circ / 0 \mu r$ & $\circ / 04 \wedge$ \\
\hline محاسباتى $n=\frac{t^{r} . s^{r}}{h^{r}}$ & $9 / 9$ & $10 / 01$ & $10 / 09$ \\
\hline
\end{tabular}

id = o.00193sesea:

$\mathrm{b}=0.00014260 / 6 \mathrm{~s}$

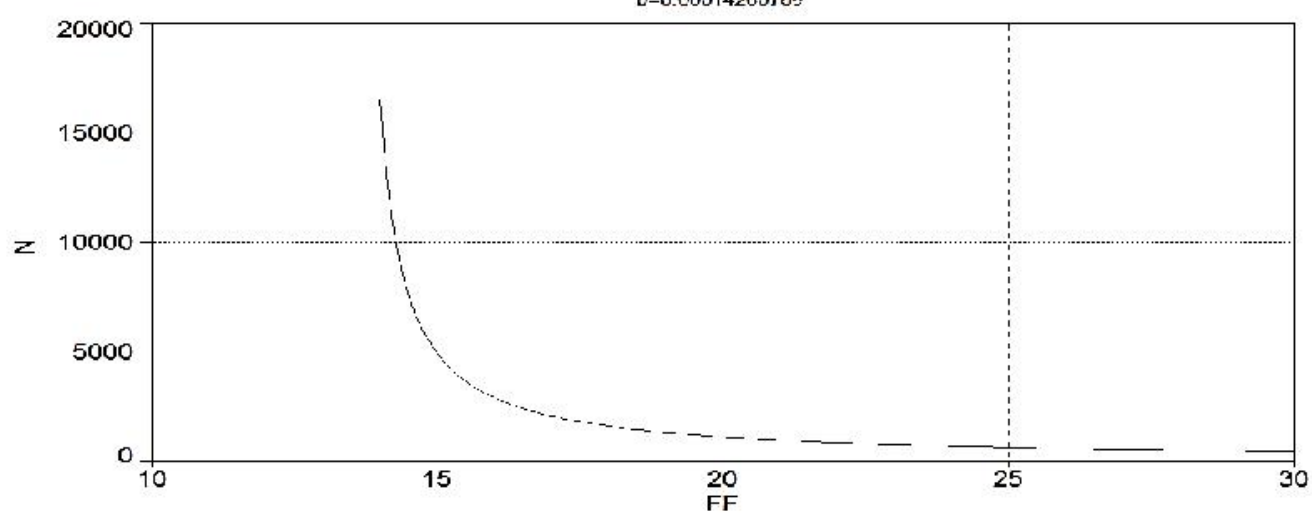

شكل r. همبستخى مقادير بهبود تابع هدف و تكرارهاى رو به بايين در مدل ICSSDOM

جدوله. خلاصه محاسبات تخمين بهينه سراسرى با روش مجانب

\begin{tabular}{|c|c|c|c|c|c|c|c|}
\hline \multirow{2}{*}{ تابع هدف موجود } & \multicolumn{5}{|c|}{ روش مجانب } & \multirow{2}{*}{ تابع هدف مدل } & \multirow{2}{*}{ درصد خطا } \\
\hline & $\mathrm{a}$ & $\mathrm{b}$ & $r^{r}$ & FSE & تابع هدف & & \\
\hline TV/I & $-0 / 0 \circ Y$ & $0 / 0001$ & $\circ / \Lambda V \mid$ & $419 / 1$ & $\mid r / \Delta \wedge$ & $14 / 49$ & $+9 \%$ \\
\hline
\end{tabular}


جدول • ا. تنظيم بهينه دريجهها و سازههاى كتترل در گزينه سوم ( گزينه برتر ) براى روز اول

\begin{tabular}{|c|c|c|c|}
\hline نوع و شماره دريجه & بازشدكى بهينه(cm) & دبى مورد نياز (Lit/s) & تحويل بهينه (Lit/s) \\
\hline دريجه آبخير $)$ & $1 r / 9$ & $r / 9 / 0$ & IVA \\
\hline دريجه آبخير ( & $r / 9$ & $\Delta V$ & 49 \\
\hline دريجه آبخير ( & $V / V$ & VT & 90 \\
\hline دريجه كنترل (ch, & $9 / \pi$ & - & - \\
\hline دريجه آبخير ( & $9 / 1$ & $\Delta V$ & 49 \\
\hline دريجه آبخير ( & $\mid r / V$ & $\Lambda \kappa / 9$ & 99 \\
\hline
\end{tabular}

اهداف و شاخصها را حتى المقدور به مقدار ايدهآلشان نزديك

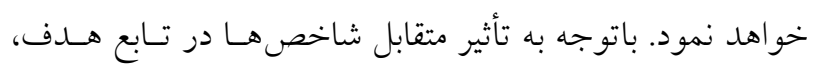

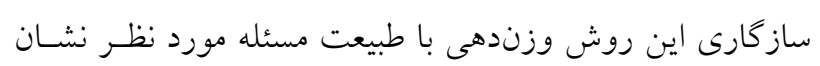

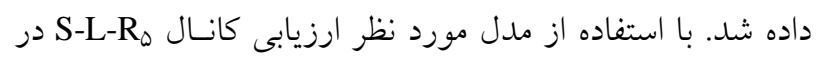

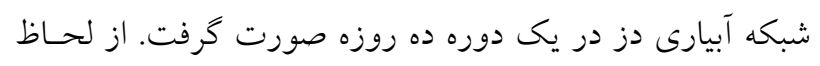

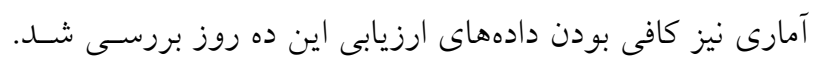

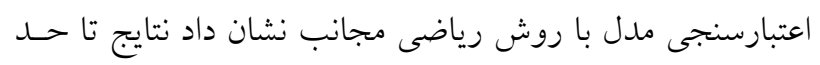

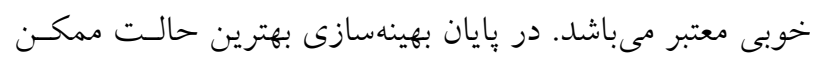

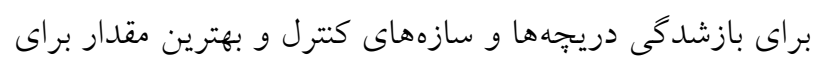

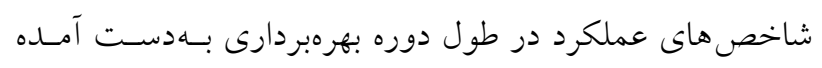

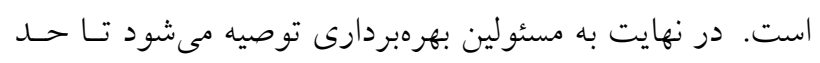

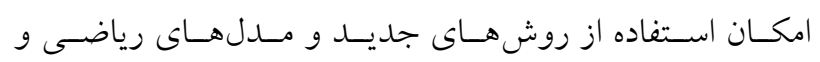
كامييوترى را كه روز به روز توسعه جشم گيرى مسى يابنــ و و بـهـ

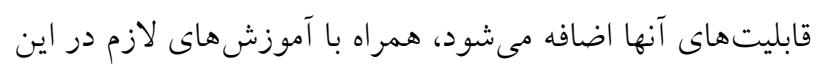

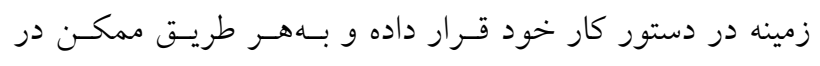

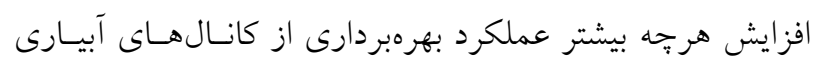

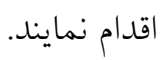

جهـارم OV ليتر در ثانيه بــوده اسـت. بـاتوجسه بـه كمبـود آب

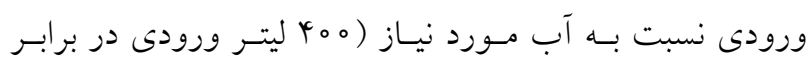

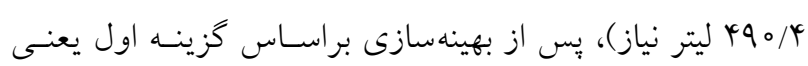

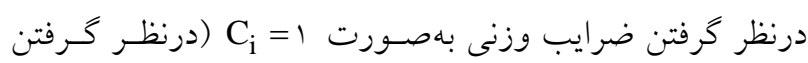

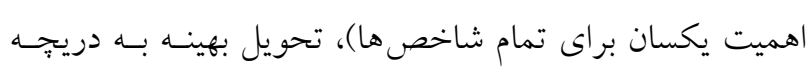

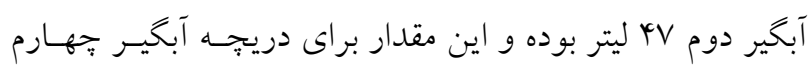

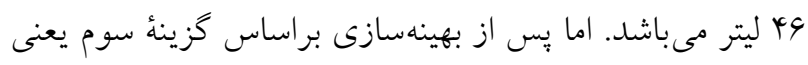

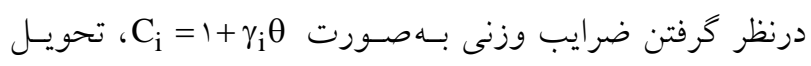
بهينه به هر دو دريجه و كز ليتر در ثانيه بوده است.

\section{نتيجه گيرى}

روش بيشنهادى وزندهى مى تو اند بهعنوان يـك روش ابتكـارى

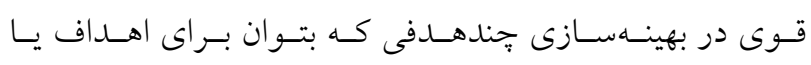

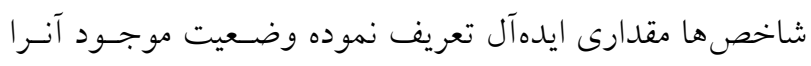

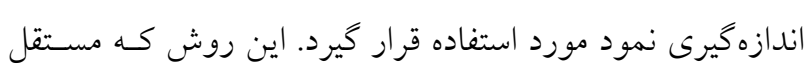

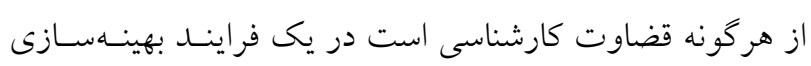

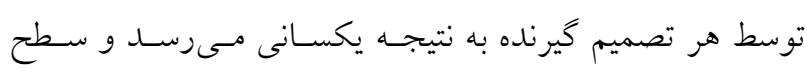

\section{منابع مورد استفاده}

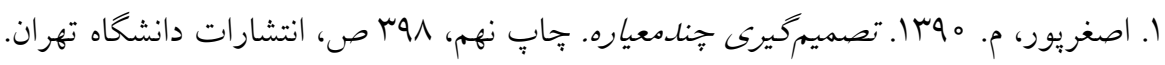

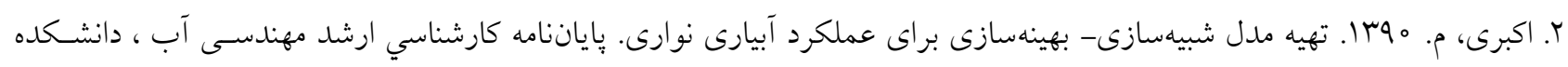

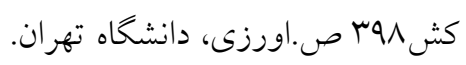

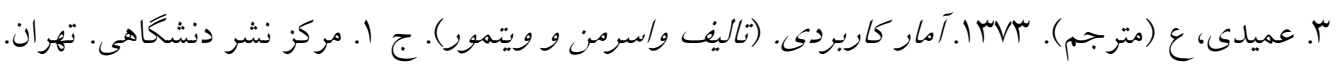




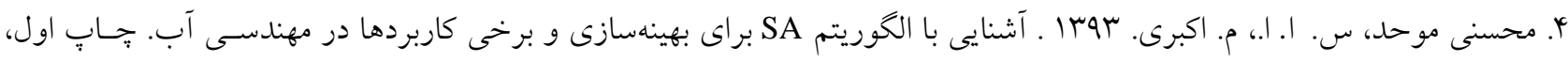

$$
\begin{aligned}
& \text { انتشارات دانشخاه اراك. } \\
& \text { ه. محسنى موحد، س. ا. ا.، و م. ج. منعم. و^با. معرفى يك مدل رياضى جديد براى ارزيابى و بهينهسازى عملكرد كانالهاى آبيـارى. }
\end{aligned}
$$

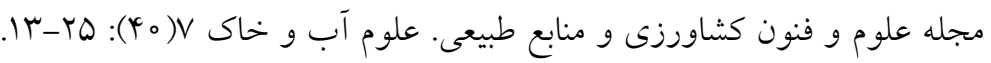

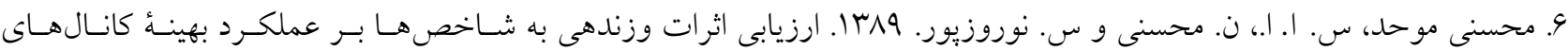

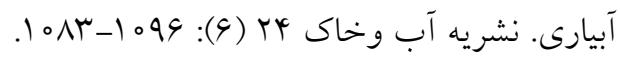

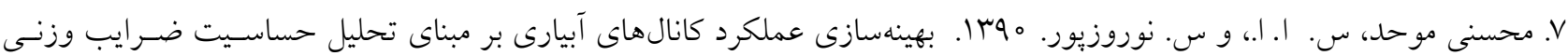

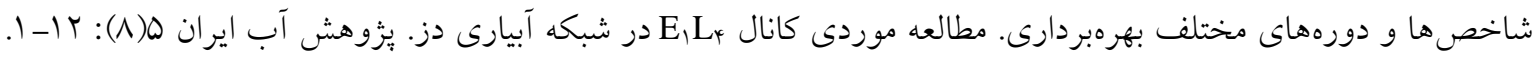

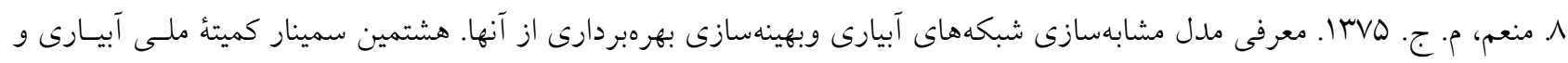

$$
\begin{aligned}
& \text { زهكشى. تهر ان. }
\end{aligned}
$$

9. Ghumman, A. R., Z. Khan and H. Turral. 2009. Study of feasibility of night-closure of irrigation canals for water saving. J. Agricultural Water Management 96:457-464.

10. Javaid, A. and T. Muhammad. 2011. Flexibility analysis of irrigation outlet structures using simulation of irrigation canal hydrodynamic model. J. Irrigation Sci. 29: 127-134.

11. Laarhoven, P. J., E. H. Aarte and J. K. Lenstra. 1992. Job shop scheduling by simulated annealing. J. of Operation Res. 40: 113-125.

12. Molden, D. J. and T. K. Gates. 1990. Performance measures for evaluation of irrigation water delivery systems. J. of Irrigation and Drainage Eng. 116(6): 804-822. 


\title{
The Best Weighted Combination of Indicators in Optimal Operation of Irrigation Canals Using SA Algorithm and Asymptotic Method for Validation
}

\author{
S. A. Mohseni Movahed ${ }^{* 1}$ \\ (Received: July 23-2014; Accepted: March 5-2016)
}

\begin{abstract}
In the ICSSDOM simulation-optimization model, simulated annealing algorithm is combined with a hydrodynamic simulation model named ICSS. In this model the ability of weighting of indicators is also considered. In this study, using this model the performance of the S-L-R5 canal in the DEZ irrigation network was evaluated in a period of 10 days. With presenting a proposed method for weighting the indicators and its various options, using parametric sensitivity analysis, optimal adjustment of intake and check structures was obtained. It was found if the coefficient of each index is selected as a direct ratio of the ideal improvement potential of the indicator, the percentage of the improvement is more than the other investigated options. In addition, due to the interaction of the indicators in the multi-objective functions, the consistency of the weighting method with the nature of the optimization problem in this study has been shown. Statistically, the adequacy of the 10-day period of study was confirmed. The model validation with mathematical asymptote method shows $6 \%$ error which indicates the model is valid. For example, on the first day, based on the option three (The optimal option), the optimal gate opening for 5 intakes and one check control was between 3.9 to $14.7 \mathrm{Cm}$. In this condition optimal delivery was between 46 to 178 liters per second.
\end{abstract}

Keywords: Asymptote method, consistency test, ICSSDOM, Ideal improvement potential, SA algorithm.

\footnotetext{
1. Dept. of Water Eng., College of Agriculture., Arak Univ., Arak, Iran

*: Corresponding Author, Email: movahed244@yahoo.com
} 